\title{
Site of action of ipratropium bromide and clinical and physiological determinants of response in patients with asthma
}

\author{
MR PARTRIDGE, KB SAUNDERS \\ From the Department of Medicine, The Middlesex Hospital and Medical School, London
}

ABSTRACT It has been suggested that in normal subjects inhaled anticholinergic agents have a preferential dilating effect on large central airways. We therefore studied 21 patients with asthma to see if response to inhaled ipratropium bromide was related to the initial central or peripheral site of major airway narrowing. Fourteen out of 21 patients with asthma increased their Vmax more than $10 \%$ after ipratropium but when assessed by air and helium/oxygen $\left(\mathrm{He} / \mathrm{O}_{2}\right)$ flow-volume curves, responders and non-responders to $\mathrm{He} / \mathrm{O}_{2}$ breathing were divided equally between those who benefited from the drug, and those who did not. There were no significant differences in percentage improvement in $\dot{V} \max$ between initial responders, and initial non-responders to $\mathrm{He} / \mathrm{O}_{2}$ breathing. Furthermore the results from air and $\mathrm{He} / \mathrm{O}_{2}$ flow-volume curves suggest that, contrary to some previous reports (not in asthmatics), inhaled ipratropium has a generalised action throughout the airways. There were no differences in severity of airflow obstruction, nor in age, sex, smoking history, or atopic status between those who benefited from ipratropium and those who did not. However, those improving after the drug had a significantly longer history of asthma than those who did not.

Although resting vagal tone is normally present throughout the bronchial tree, ${ }^{1}$ it has been claimed that in normal subjects inhaled anticholinergic agents act mainly on the large central airways, ${ }^{1-3}$ although Douglas and colleagues ${ }^{4}$ disagree.

In some patients with asthma the helioxygen technique ${ }^{5}$ suggests that the major site of narrowing is in the larger central airways, whereas in others the main obstruction is more peripheral.

If the anticholinergic agent ipratropium acts mainly on large airways, it should be more effective in patients with predominant large airway obstruction, and this is the hypothesis tested here. The use of the helioxygen technique to test the effect of ipratropium in asthmatic patients has not been reported previously.

Address for reprint requests: MR Partridge, The London Chest Hospital, Bonner Road, London E1.

\section{Methods}

Twenty-one patients with airflow obstruction which had been shown to vary spontaneously or with treatment took part in the study and their clinical details are shown in table 1. Atopic status and smoking status were categorised in the same way as by Antic and Macklem. ${ }^{6}$ All patients attended the laboratory in an afternoon having had no bronchodilator for at least 12 hours. Flow-volume curves were obtained using an Ohio 840 electronic spirometer from which flow and volume signals were taken to an Electronics for Medicine DR8 photographic recorder. The patients performed a minimum of three forced expirations breathing air and results were accepted only if the vital capacity was reproducible to within $100 \mathrm{ml}$. Three further forced expirations were then performed after breathing a mixture of $80 \%$ helium, $20 \%$ oxygen $\left(\mathrm{He} / \mathrm{O}_{2}\right)$ until end-tidal nitrogen concentration was less than $5 \%$ when measured by a mass spectrometer (Centronics MGA 
Table 1 Details of patients studied

\begin{tabular}{rlllll}
\hline & $\begin{array}{c}\text { Age } \\
(y r)\end{array}$ & Sex & $\begin{array}{l}\text { Smoking } \\
\text { history }\end{array}$ & $\begin{array}{l}\text { Duration } \\
\text { ofasthma } \\
(\text { yrs })\end{array}$ & $\begin{array}{l}\text { Atopic } \\
\text { status* }\end{array}$ \\
\hline 1 & 44 & M & NS & 9 & - \\
2 & 56 & F & S & 36 & - \\
3 & 24 & M & S & 5 & + \\
4 & 56 & M & NS & 20 & - \\
5 & 71 & M & NS & 60 & - \\
6 & 51 & F & ES & 1 & - \\
7 & 69 & F & NS & 2 & - \\
8 & 69 & M & S & 1 & - \\
9 & 24 & M & NS & 11 & - \\
10 & 59 & F & NS & 1 & - \\
11 & 63 & F & NS & 4 & - \\
12 & 37 & M & NS & 3 & - \\
13 & 22 & F & S & 20 & - \\
14 & 67 & F & NS & 3 & - \\
15 & 52 & F & NS & 5 & - \\
16 & 21 & M & S & 11 & - \\
17 & 50 & M & S & 8 & - \\
18 & 69 & F & S & 3 & - \\
19 & 69 & F & ES & 5 & - \\
20 & 72 & M & ES & 30 & - \\
21 & 45 & M & S & 35 & - \\
\hline
\end{tabular}

*Atopic status $(-$ or + ) and smoking history (NS $=$ non-smoker. $\mathrm{ES}=$ ex-smoker, $\mathbf{S}=$ smoker) classified in the same way as by Antic and Mack lem ${ }^{6}$.

$200)$. Flow rates at $50 \%$ of vital capacity $\left(\dot{V}_{\max }{ }_{50}\right)$ were measured at BTPS and the mean flow rate from at least three curves obtained breathing air compared with those on $\mathrm{He} / \mathrm{O}_{2}$ and expressed as percentage change (the "density dependence") by the formula:

$$
\Delta \dot{\mathrm{V}} \max _{50} \%=\left(\frac{\dot{\mathrm{V}} \max _{50} \text { on } \mathrm{He} / \mathrm{O}_{2}}{\dot{V} \max _{50} \text { on air }}-1\right) 100
$$

Those with a greater than $20 \%$ response to $\mathrm{He} / \mathrm{O}_{2}$ breathing were termed "responders" and those with a less than $20 \%$ response termed "non-responders". 5

The patients then inhaled four puffs of ipratropium bromide $(0.08 \mathrm{mg})$ and air and $\mathrm{He} / \mathrm{O}_{2}$ flow-volume curves were repeated 30 minutes later. Results are expressed as a percentage improvement over baseline and compared by the paired $t$ test. Seven patients also had measurements of residual volume (RV) and total lung capacity (TLC) made in a Dubois-type body plethysmograph before and after inhalation of ipratropium. Maximum flow rates could then be compared at the same absolute lung volume before and after the bronchodilator, independently of changes in TLC, RV, or VC. We selected a volume as close as possible to $50 \%$ vital capacity before ipratropium such that flow rate could be measured at that same volume after bronchodilatation on the downstroke of the second flow-volume curve.

\section{Results}

Mean values of flow rates and vital capacity in the 21 patients weresignificantly improved after ipratropium but there was no significant difference between the mean response of $\dot{\mathrm{V}} \max _{50}$ to $\mathrm{He} / \mathrm{O}_{2}$ breathing before ipratropium compared with after inhalation of the drug (table 2). Results from the seven patients studied in the plethysmograph show significant changes in mean values of residual volume and total lung capacity after inhalation of the drug (table 3), but again there were no differences in the flow rate responses to $\mathrm{He} / \mathrm{O}_{2}$ at the same absolute lung volume before and after ipratropium.

Whereas all patients had on other occasions shown a minimum $10 \%$ improvement in $\dot{V} \max$ after inhaled $\beta_{2}$ agonists, only 14 of the 21 patients given ipratropium showed a similar improvement. Of these 14 patients who benefited from ipratropium, eight had been inital responders to $\mathrm{He} / \mathrm{O}_{2}$ breathing $\left(\Delta \dot{V} \max _{50}>20 \%\right)$ and six had been initial nonresponders $\left(\Delta \dot{V} \max _{50}<20 \%\right)$. Of the seven patients who did not improve $\mathrm{V}$ max by $10 \%$ or more after ipratropium, four were responders to $\mathrm{He} / \mathrm{O}_{2}$ breathing and three were non-responders (table 4). When magnitude of improvement of $\dot{V} \max$ after ipratropium was related to initial major site of airway narrowing, the mean percentage improvement in $\dot{V}$ max after ipratropium was $24.5 \%( \pm 18 \cdot 9)$ in those with their initial major site of flow limitation in the larger central airways (responders to $\mathrm{He} / \mathrm{O}_{2}$ breathing), against $15 \cdot 5 \%( \pm 17 \cdot 8)$ among those with preferential peripheral airway constriction (nonresponders to $\mathrm{He} / \mathrm{O}_{2}$ breathing)-a non-significant difference.

Table 2 Effect of ipratropium bromide on indices derived from the flow-volume curves obtained while breathing air helium/oxygen mixtures

\begin{tabular}{|c|c|c|c|c|}
\hline & \multicolumn{2}{|c|}{ Mean values (with standard deviation) $n=21$} & \multirow{2}{*}{$\begin{array}{l}\text { Mean percentage } \\
\text { improvement after } \\
\text { ipratropium (with } S D)\end{array}$} & \multirow{2}{*}{$\begin{array}{l}\text { Statistical significance } \\
\text { of change* } p<\end{array}$} \\
\hline & Before ipratropium & After ipratropium & & \\
\hline $\begin{array}{l}V \max \text { breathing air }(1 / \mathrm{s}) \\
V \max _{50} \text { breathing air }(1 / \mathrm{s}) \\
V_{\max }, \text { bleathing air }(1 / \mathrm{s}) \\
\text { Vital capacity }(1) \\
\text { Percentage improvement in } \mathrm{Vmax}_{50} \text { breathing } \\
\mathrm{He} / \mathrm{O}_{2} \text { compared with air }\end{array}$ & $\begin{array}{l}4 \cdot 25( \pm 1 \cdot 42) \\
1 \cdot 07( \pm 0 \cdot 83) \\
0 \cdot 37( \pm 0 \cdot 31) \\
3 \cdot 10( \pm 1 \cdot 10)\end{array}$ & $\begin{array}{l}4.96( \pm 1 \cdot 46) \\
1 \cdot 33( \pm 1 \cdot 05) \\
0.44( \pm 0 \cdot 40) \\
3 \cdot 42( \pm 1 \cdot 07) \\
30 \cdot 1( \pm 23 \cdot 5)\end{array}$ & $\begin{array}{l}+20 \cdot 4( \pm 18 \cdot 6) \\
+29 \cdot 5( \pm 31 \cdot 3) \\
+23 \cdot 8( \pm 31 \cdot 9) \\
+12 \cdot 9( \pm 15 \cdot 5)\end{array}$ & $\begin{array}{l}0.001 \\
0.005 \\
0.002 \\
0.001 \\
\text { NS }\end{array}$ \\
\hline
\end{tabular}

* Paired $t$ test. NS = not significant.

Vmax is equivalent to peak expiratory flow rate.

$V \max _{30}$ and $V \max _{20}$ refer to maximum flow rates at 50 and $25 \%$ of vital capacity. 
Table 3 Lung volumes and flow rate responses to helium/ oxygen breathing in the seven patients studied in a plethysmograph before and after ipratropium

\begin{tabular}{|c|c|c|c|}
\hline & \multicolumn{2}{|c|}{ Mean values (with standard deviation) } & \multirow{2}{*}{$\begin{array}{l}\text { Statistical significance } \\
\text { of change } e^{*}<\end{array}$} \\
\hline & Before ipratropium & After ipratropium & \\
\hline $\begin{array}{l}\text { Residual volume (1) } \\
\text { Total lung capacity (1) }\end{array}$ & $\begin{array}{l}4 \cdot 37( \pm 2 \cdot 8) \\
6 \cdot 80( \pm 2 \cdot 8)\end{array}$ & $\begin{array}{l}2 \cdot 84( \pm 1 \cdot 2) \\
5 \cdot 78( \pm 2 \cdot 0)\end{array}$ & $\begin{array}{l}0.001 \\
0.001\end{array}$ \\
\hline $\begin{array}{l}\text { Density dependence of flow rates at same absolute lung volume, } \\
\mathrm{He} / \mathrm{O} \text {; compared with air }(\%)\end{array}$ & $+34 \cdot 7( \pm 20 \cdot 9)$ & $+33 \cdot 3( \pm 23 \cdot 7)$ & NS \\
\hline
\end{tabular}

* Paired $t$ test. NS = not significant.

All flow rates after ipratropium were measured at the same volume as before ipratropium (see text).

Table 4 Response to ipratropium related to initial response to $\mathrm{He} / \mathrm{O}_{2}$ breathing. Vmax is the peak expiratory flow rate $(P E F R)$

\begin{tabular}{lll}
\hline & $\begin{array}{l}\text { Response o, Vmax }(P E F R) \text { to } \\
\text { ipratropium }\end{array}$ \\
\cline { 2 - 3 } & $<10 \%$ increase & $>10 \%$ increase \\
\hline$\Delta \operatorname{Vmax}_{50}\left(\mathrm{He} / \mathrm{O}_{2}\right)$ & 3 & 6 \\
$<20 \%$ increase & 4 & 8 \\
$\Delta \operatorname{Vmax}_{50}\left(\mathrm{He} / \mathrm{O}_{2}\right)$ & & \\
$>20 \%$ increase & & \\
\hline
\end{tabular}

There were no differences in severity of airflow obstruction, nor in age, sex, smoking history, or atopic status between the 14 patients who benefited from ipratropium and those who did not. However, those improving after the drug had a significantly longer history of asthma (mean 20.4 years $\pm 19 \cdot 9$ ) than those who did not improve (mean 6.2 years \pm $10 \cdot 2$, unpaired $t$ test $\mathrm{p}<0.05$ ).

\section{Discussion}

The technique of comparing air and $\mathrm{He} / \mathrm{O}_{2}$ flowvolume curves is a widely accepted method of determining the main site of airway narrowing, and the theoretical background ${ }^{5} 7$ is supported by validation in dogs. ${ }^{8}$ However, the actual size of airways where a laminar and therefore density independent flow regime prevails may be surprisingly large. ${ }^{\circ}$ Using this technique, Ingram and colleagues ${ }^{2}$ have suggested that in normal subjects inhalation of anticholinergic agents is associated with preferential large airway dilation. Hensley and colleagues ${ }^{3}$ have measured anatomical dead space before and after inhaled atropine in normal subjects, and reviewed published reports to suggest that this measurement is weighted towards dimensional changes in the more proximal conducting airways. They have shown increases in anatomical dead space after atropine and interpret the findings (by a comparison with the peripheral effects of isoprenaline) to confirm that the predominant site of action of inhaled atropine is on the larger central airways. De Troyer and colleagues ${ }^{1}$ have compared the effects of large doses of inhaled ipratropium bromide with those of intravenous atropine, and suggested that the bronchodilation produced by the inhaled drug is confined to the large airways, whereas intravenous atropine has an additional peripheral airway effect.

In our 21 patients with asthma the mean density dependence $\left(\Delta \dot{\mathrm{V}} \max _{50} \% \mathrm{He} / \mathrm{O}_{2}\right)$ after ipratropium was the same as before inhalation of the drug. This suggests that there was no systematic change in the site in the airways at which maximum flow is determined (the flow-limiting segment). However, when comparing flow rate response to $\mathrm{He} / \mathrm{O}_{2}$ breathing before and after administration of a drug, when there may be significant changes in vital capacity, $\operatorname{V} \max _{50}$ may be difficult to interpret if absolute lung volumes are not measured. Under such circumstances although flow rates at $50 \%$ of exhaled vital capacity are being compared each time, because of changes in residual volume and total lung capacity the absolute lung volume at which measurements are being made may well be different. To counteract this source of error we did measure flow rates at the same absolute lung volume in a smaller subgroup of seven patients. Flow rate response to $\mathrm{He} / \mathrm{O}_{2}$ breathing at the same absolute lung volumes was not significantly different after the drug compared with before and we therefore feel that the conclusions drawn from the results of the whole group are valid. Although most previous workers have suggested that the action of ipratropium is localised to the larger central airways in normal subjects, our findings are consistent with more recent studies on normal subjects $^{4}$ and on patients with chronic bronchitis ${ }^{10}$ in whom inhaled ipratropium also had a generalised action.

These different findings are unlikely to be the result of drug dosage, for a central preferential effect has been claimed in normal subjects ${ }^{1}$ using three times the dose used by ourselves and Douglas and colleagues. ${ }^{410}$ They are also unlikely to be caused by the techniques of assessment because contradictory results have been achieved with the same

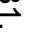
(n) 
techniques ${ }^{14}$ and concordant results with different techniques. ${ }^{23}$ One source of difference might be a patchy distribution of narrowing in asthmatic subjects, with narrowing at segmental levels in some parts of the lung and in smaller airways in others.

Whatever the reason for the lack of correlation between initial site of major narrowing and response to ipratropium, this finding apparently precludes the possibility of prescribing different bronchodilators according to an individual patient's site of major obstruction-for example, ipratropium for a patient with large airway obstruction.

We therefore looked for other clinical or physiological features which might predict response to ipratropium. There were no differences in severity of airflow obstruction, nor in age, sex, smoking history, or atopic status between those who benefited from ipratropium and those who did not. However, those who benefited from the drug had a significantly longer history of asthma than those who did not. This may imply that cholinergic influences become relatively more important in determining bronchial calibre with length of history of disease. Whether this is the result of an increase in vagal tone or possibly a loss of number or function of $\beta$ receptors remains uncertain.

Others have suggested that patients with chronic bronchitis respond well to ipratropium bromide. ${ }^{10}$ Some of our patients with asthma had chronic productive cough-although we did not formally assess these symptoms-but parallel work from this laboratory ${ }^{11}$ suggests that the presence of a chronic productive cough in patients with asthma does not distinguish responders to ipratropium.

In conclusion, results of this study suggest that, contrary to some previous work in normal subjects ${ }^{13}$ the action of ipratropium in patients with asthma is one of generalised bronchodilation of the tracheobronchial tree, but this conclusion is in agreement with other studies in normal subjects and in patients with chronic bronchitis. ${ }^{4}$ 10 Helioxygen MEFV curves do not give information which enable the response to ipratropium to be predicted.

We acknowledge with thanks the technical assistance of Miss AC Watson. During the course of this work MRP was in receipt of a Sir Jules Thorn Research Fellowship and the study was supported by an equipment grant (no 549) from the British Heart Foundation.

\section{References}

${ }^{1}$ De Troyer A, Yernault JC, Rodenstein D. Effects of vagal blockade on lung mechanics in normal man. $J$ Appl Physiol 1979;46:217-26.

2 Ingram RH, Wellman JJ, McFadden ER, Mead J. Relative contributions of large and small airways to flow limitation in normal subjects before and after atropine and isoproterenol. J Clin Invest 1977;59:696-703.

${ }^{3}$ Hensley MJ, O'Cain CF, McFadden ER, Ingram RH. Distribution of bronchodilation in normal subjects: beta agonist versus atropine. J Appl Physiol 1978;45: 778-82.

4 Douglas NJ, Sudlow MF, Flenley DC. Effect of an inhaled atropine-like agent on normal airway function. $J$ Appl Physiol 1979;46:256-62.

5 Despas PJ, Leroux M, Macklem PT. Site of airway obstruction in asthma as determined by measuring maximal expiratory flow breathing air and a Heliumoxygen mixture. J Clin Invest 1972;51:3235-43.

6 Antic R, Macklem PT. The influence of clinical factors on site of airways obstruction in asthma. Am Rev Respir Dis 1976;114:851-9.

7 Dosman J, Bode F, Urbanetti J, Martin R. Macklem PT. The use of a helium-oxygen mixture during maximum expiratory flow to demonstrate obstruction in small airways in smokers. J Clin Invest 1975;55:1090-9.

8 Barnett TB. Effects if helium and oxygen mixtures on pulmonary mechanics during airway constriction. J Appl Physiol 1967;22:701-13.

9 Mink S, Ziesmann M., Wood LDH. Mechanisms of increased expiratory flow during $\mathrm{HeO}$; breathing in dogs. J Appl Physiol 1979;47:490-502.

10 Douglas NJ, Davidson I, Sudlow MF, Flenley DC. Bronchodilation and the site of airway resistance in severe chronic bronchitis. Thorax 1979;34:51-7.

11 Ullah M, Saunders KB. Influence of age on response to ipratropium and salbutamol in asthmatic patients. Thorax $1981 ; 36: 523-29$ 